\title{
POTENTIAL ROLE OF FINITE ELEMENT MODEL OF ABDOMINAL AORTIC ANEURYSM IN CLINICAL DECISION MAKING
}

\author{
Sunčica Popović ${ }^{1,2}$, Igor Končar ${ }^{3}$, Lazar Davidović ${ }^{3}$ \\ ${ }^{1}$ Faculty of Medicine, University of Belgrade, Serbia \\ ${ }^{2}$ Clinic for Vascular and Endovascular Surgery, Clinical Center of Serbia \\ ${ }^{3}$ Mentors: Clinic for Vascular and Endovascular Surgery, Clinical Center of Serbia \\ Contact e-mail: suncicapbg@gmail.com
}

Sažetak

Uvod: Smatra se da ruptura AAA nastaje kao posledica poremećaja ravnoteže između najvećeg napona u zidu i jačine zida. Model konačnih elemenata (MKE) daje podatke o regionalnoj raspodeli napona u zidu AAA kao i o mestu najvećeg napona u zidu (peak wall stressPWS), kao preciznijeg prediktora rupture.

Cilj: Ispitivanje učestalosti promene odluke o tretmanu AAA kod pacijenata kod kojih su korišćeni MKE i paramateri biomehaničke analize, kao preciznija metoda za utvrđivanje rizika od rupture AAA.

Materijal i metode: Istraživanje je sprovedeno $u$ vidu prospektivne studije koja je obuhvatila 48 bolesnika sa asimptomatskom AAA. Analizom konačnih elemenata određeni su specifični anatomski i biomehanički parametri. Na taj način omogućeno je definisanje lokalizacije najvećeg napona u zidu i dijametra aorte, parijetalnog tromba u nivou najvećeg napona kao i vrednosti maksimalno izmerenog dijametra (MD) i dijametra ekvivalentnog riziku od rupture (DERR).

Rezultati: Kod 20 pacijenata $(41,67 \%)$ bi potencijalno došlo do promene odluke o načinu lečenja AAA na osnovu vrednosti DERR, kao preciznijeg prediktora rupture. U okviru njih, 16 pacijenata (80\%) ne bi bilo podvrgnuto operativnom lečenju, budući da je njihov DERR bio manji od graničnih $55 \mathrm{~mm}$. Kod preostala 4 pacijenta (20\%), AAA bi potencijalno bile operativno tretirane, jer je njihov DERR bio veći od graničnih $55 \mathrm{~mm}$.

Zaključak: Kod 41,67\% pacijenata koji su bili deo naše studije došlo bi do promene odluke o tretmanu aneurizme abdominalne aorte (AAA).

Ključne reči: aneurizma abdominalne aorte, maksimalni napon u zidu, promena odluke o lečenju.

\section{Abstract}

Introduction: AAA rupture occurs as a consequence of the imbalance between aortic wall's strength and the loading stress. FEM provides information on the regional distribution of stresses in the wall of AAA and proved to be a more accurate predictor of aneurysm rupture. The risk of rupture is expressed through peak wall stress (PWS) and rupture risk equivalent diameter (RRED) that includes wall strength in calculation.

Aim: To determine the influence of FEM and subsequent biomechanical analysis of AAA on treatment decisions in common clinical practice.

Material and methods: This prospective study included 48 patients with asymptomatic AAA. The specific anatomical and biomechanical parameters were determined by a FEM analysis: location of the PWS and diameter of the aorta, parietal thrombus in the level of PWS and the maximum value of the measured diameter (MD) as well as rupture risk equivalent diameter (RRED). Decision of treatment would change if maximal aneurysm diameter and RRED are on different sides of the $55 \mathrm{~mm}$ that is contemporary treatment threshold for AAA.

Results: In 20 patients (41.67\%) values of RRED could change treatment decisions. Four patients (20\%) with aneurysm diameter (MD) less than $55 \mathrm{~mm}$ would be transferred to the group of patients with indications for surgical treatment because their RRED was higher than the limit of $55 \mathrm{~mm}$. Sixteen patients (80\%) would be transferred to the group of patients for further follow up without surgical treatment, because their RRED was less than the limit of $55 \mathrm{~mm}$ although their MD was higher than $55 \mathrm{~mm}$.

Conclusion: Finite element model (FEM) of abdominal aortic aneurysm (AAA) and subsequent biomechanical analysis would lead to change of surgical indications for treatment of AAA in almost half of included patients.

Key words: Abdominal aortic aneurysm, peak wall stress, finite element model analysis, changing decision about treatment. 


\section{Introduction}

Rupture of abdominal aortic aneurysm (AAA) is one of the major causes of death and it is associated with a mortality rate of $70-90 \%$, especially in men older than 65 years [1]. The high morbidity and mortality due to the presence of AAA is a consequence of complications such as thrombosis, embolization and rupture causing heavy hemorrhagic shock. Despite the fact that the AAA diameter greater than $55 \mathrm{~mm}$ is an indication for elective surgery, some studies have shown that the aneurysm with a diameter less than $55 \mathrm{~mm}$ could rupture, while some aneurysms larger than $55 \mathrm{~mm}$ in diameter never rupture $[2,3,4]$. Factors that contribute to the risk of rupture are aneurysm morphology, female gender, hypertension, smoking, family predisposition and the presence of intraluminal thrombus $[5,6]$. Rupture risk assessment in AAA patients burdened with the aforementioned risk factors directly affects the decision on surgical treatment. The question that arises when observing the optimal solution for these patients is to predict the accurate moment of aneurysm rupture. The main predictor of aneurysm rupture accepted in the common practice is aneurysm diameter greater than $55 \mathrm{~mm}$.

The finite element model (FEM) is a numerical concept based on a computer program that divides any solid body on a large number of small parts, whereby together form the equivalent biomechanical model of AAA [7]. The geometry of the redesigned models, systemic arterial pressure and flow parameters determine the interaction between mechanical stress and strain of the vessel wall. AAA rupture occurs as a result of imbalance between maximum wall stress and the strength of the wall. In this way, FEM provides information on the regional distribution of stresses in the wall and the place in the wall where stress is the greatest in AAA (peak wall stress) as well as more accurate predictors of rupture. In this regard, the role of FEM, as accurate method in risk assessment for AAA rupture could change surgical indications for treatment of patients with this problem. Rupture risk equivalent diameter (RRED) takes into account the data on the regional distribution of stresses in the wall, as well as the exact place the greatest stress.

The aim of this study is to determine the influence of FEM and subsequent biomechanical analysis of AAA on treatment decisions in common clinical practice.

\section{Material and methods}

\section{Selection of patients}

The research was conducted as a prospective study that included 48 patients with asymptomatic AAA. They were followed and treated at the Clinic for Vascular and Endovascular Surgery, Clinical Center of Serbia, in the period from 1.1.2007. to 1.1.2015.. The clinical trial was approved by the local ethics committee and written informed consent was obtained from all participants prior to beginning the study.

Criteria for inclusion in the study: patients with aneurysmal dilatation of infrarenal aorta greater than $40 \mathrm{~mm}$, verified by ultrasonography and multi-slice computed tomography (MSCT). Exclusive criteria from the study: patients younger than 50 years, patients with heritable connective tissue disorders (Ehlers-Danlos syndrome, Marfan syndrome etc.), autoimmune connective tissue disorders (systemic lupus erythematosus, mixed connective tissue disease etc.) and other connective tissue disorders (scurvy), malignant disease or a traumatic, infectious or already surgically treated AAA.

\section{Biomechanical analysis}

All patients were subjected to MSCT examination with standard resolution (the distance between the two sections was from $1 \mathrm{~mm}$ ) (Picture 1). Surgical treatment, which was indicated in some patients, was conducted in accordance with current recommendations of good clinical practice and the results of the treatment were not considered in this study. Images of AAA patients made during MSCT examination, were analyzed by an operator using a special software program "A4clinics" (VASCOPS GmbH, Graz, Austria) based on finite element

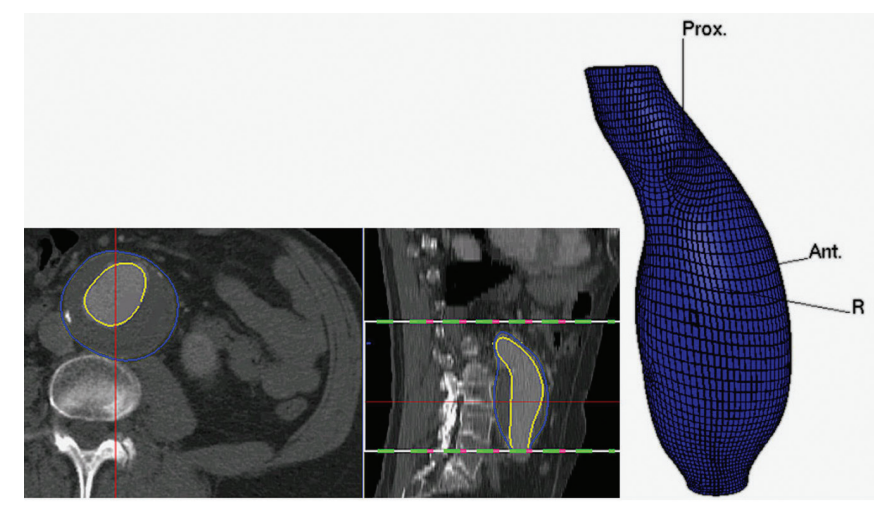

Picture 1. AAA recordings made by MSCT. 1a.Transverse section of abdomen at the level of vertebra L2 (yellow contour is marked free part of the lumen, the blue contour is marked outer wall of AAA). Intraluminal thrombus is located between these two contours. Determination of the lumen and the outer wall of AAA is the first step in the assessment of biomechanical parameters. 1b. Reconstruction of an aneurysm in the sagittal plane. 1c. Reconstructed aneurysm by finite element method in the form of mesh (finite element mesh). Prox.-upper part, Ant.-front part of the aneurysm. 
model (FEM). FEM was used to assess the biomechanical parameters as value of the maximum wall stress (peak wall stress) and the RRED value. After downloading the images that represent snapshots of AAA made by MSCT examination from "DICOM" (Digital Imaging and Communication in Medicine) file in the program "A4Clinics", the program automatically determined limit lumens, the external border of the aortic wall and created finite element mesh. The intensity and stress distribution in every part of the created mesh were structurally analysed (Picture 2). In this way, it was possible to define the location of the maximum wall stress, the diameter of the aorta and parietal thrombus in the level of the maximum wall stress. Following reconstruction, the model revealed values of RRED according to the assessed wall strength.

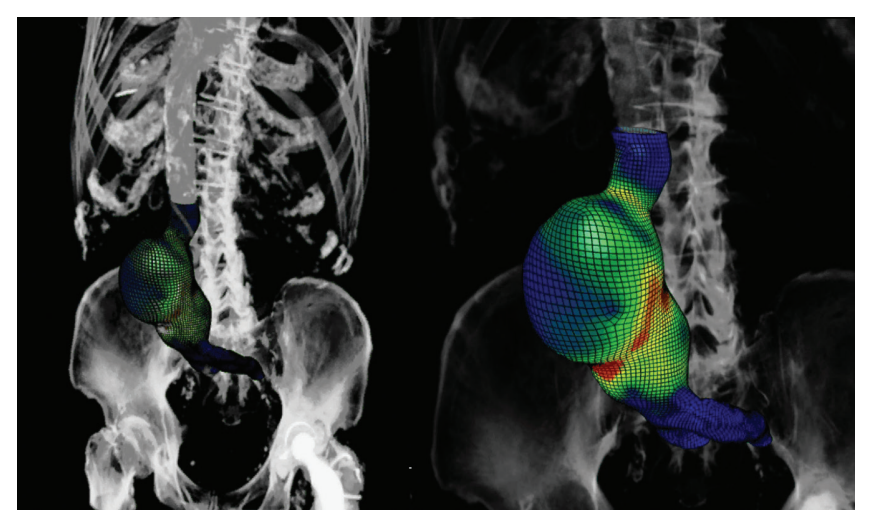

Picture 2. Reconstruction of 3D models AAA by finite element method (FEM) using the software program "A4clinics". The second step in the assessment of biomechanical parameters is creation a mesh and determination of stress and its distribution in any part of the mesh. The highest values of stress in the wall of the aneurysm are marked in red, blue is the point of least stress, and green and yellow are places of intermediate stress.

\section{The observed parameters}

Before surgery, the demographic and clinical characteristics of patients were taken into account (age, gender, comorbidities). The specific anatomical and biomechanical parameters were calculated: maximum AAA diameter (MD), rupture risk equivalent diameter (RRED), difference between the previous two diameters given in absolute value (DD), difference between the previous two diameters in percentages (DP). If RRED was higher than the MD, this difference was noted as positive and if the RRED was lower than MD this difference was noted as negative. The following parameters were also calculated using this program: maximum luminal diameter (MLD), maximum thickness of the intraluminal thrombus (MTIT), total volume of AAA (TVA), total luminal volume (TLV), intraluminal thrombus volume (ITV), proportion of intraluminal thrombus in a total volume of AAA (TVA/ITV), proportion of intraluminal thrombus in the total volume of AAA expressed in percentage (PTAV). RRED represents a virtual value obtained biomechanical analysis parameters corresponding AAA and based on epidemiological and biomechanical data obtained by examining the characteristics of AAA in many patients. As a more precise predictor of rupture, RRED takes into account the data on the regional distribution of stresses in the wall, as well as the exact place of the greatest stress. The parameters related to the wall stress and the consequent risk of rupture were: maximum stress in the wall (peak wall stress) (PWS), average value of stress in the wall (AWS), maximum value of the index that shows the risk of rupture (MIR), average value of the index that shows the risk of rupture (AIR), maximum wall stress in the area of intraluminal thrombus (MST), mean value of the wall stress in the area of intraluminal thrombus (AST), maximum value of the index that shows the risk of rupture in the region intraluminal thrombus (MIRT), the average value of the index that shows the risk of rupture in the area of intraluminal thrombus (AIRT).

In order to estimate the frequency of changes in the decision for surgical treatment, patients were divided into 2 groups: 1 . the first group of patients consisted of 28 patients, in whom the rupture risk equivalent diameter (RRED) and the maximum AAA diameter (MD) were on the same side of the boundary values of diameter $55 \mathrm{~mm}$, ie. those in which there would be no change in decision on further treatment of AAA, 2. the second group of patients consisted of 20 patients which RRED and MD values were from different sides of the boundary value of 55 $\mathrm{mm}$. This group was, therefore, covered by the patients with RRED value was more then $55 \mathrm{~mm}$ and MD value were less then $55 \mathrm{~mm}$ and vice versa, ie. where a decision about the future treatment of AAA could be altered. The value of the MD and RRED and the corresponding biomechanical parameters were compared between the two groups.

\section{Statistical analysis}

Statistical analysis was performed using modern descriptive and analytical statistics methods and software package SPSS 22.0. Student's t-test and $\chi^{2}$ - test were used from the analytical methods. The statistically significant was considered $\mathrm{p}<0.05$, a highly statistically significant was considered $\mathrm{p}<0.01$. 
Results

The study included 48 patients with AAA who were treated at the Clinic for Vascular and Endovascular Surgery, Clinical Center of Serbia. Tested patients were predominantly male, 45 of them $(93.8 \%)$, remaining 3 patients were female (6.2\%). All patients who were part of this study were divided into 2 groups. The first group of patients consisted of 28 patients $(58.33 \%)$ and the second group consisted of 20 patients $(41.67 \%)$.
Comorbidities

The average age of patients in the first group was $69.61 \pm 8.34$ years, while the other group was $68.95 \pm 6.67$ years. Comorbidities, risk factors, previous pharmacological (statins) and surgical therapy and their frequency were observed among patients in both groups. The most frequent comorbidities and risk factors in both groups were hypertension, coronary disease, smoking and insignificant carotid disease (Table $\mathbf{1}$ ).

Table 1. Comorbidities of patients in both groups. HTA- arterial hypertension, PTCA- percutaneous transluminal coronary angioplasty, CABG- coronary artery bypass graft, PVD- peripheral vascular disease, PVP- peripheral vascular procedure, CE-carotid endarterectomy.

\begin{tabular}{|l|c|c|}
\hline COMORBIDITIES & FIRST GROUP & SECOND GROUP \\
\hline UNREGULATED HTA & $26(54,2 \%)$ & $15(31,3 \%)$ \\
\hline DYSLIPIDEMIA & $6(12,8 \%)$ & $5(10,6 \%)$ \\
\hline PRIOR USE OF STATINS & $12(25,5 \%)$ & $2(4,3 \%)$ \\
\hline DIABETES MELLITUS & $3(6,3 \%)$ & $2(4,2 \%)$ \\
\hline SMOKING & $15(31,3 \%)$ & $14(29,2 \%)$ \\
\hline HOSTILE ABDOMEN & $8(16,7 \%)$ & $6(12,5 \%)$ \\
\hline CORONARY DISEASE & $16(33,3 \%)$ & $10(20,8 \%)$ \\
\hline PREVIOUS PTCA OR CABG & $6(12,5 \%)$ & $2(4,2 \%)$ \\
\hline ARRHYTHMIA & $6(12,5 \%)$ & $2(4,2 \%)$ \\
\hline RESPIRATORY FAILURE & $7(14,6 \%)$ & $6(12,5 \%)$ \\
\hline KIDNEY DISEASE & $4(8,3 \%)$ & $3(6,3 \%)$ \\
\hline PVD & $3(6,3 \%)$ & $4(8,3 \%)$ \\
\hline PREVIOUS PVP & $1(2,1 \%)$ & $2(4,2 \%)$ \\
\hline INSIGNIFICANT CAROTID DISEASE & $10(20,8 \%)$ & $5(10,4 \%)$ \\
\hline INCORRECTABLE CAROTID ARTERY DISEASE & $0(0 \%)$ & $0(0 \%)$ \\
\hline PREVIOUS CE & $4(8,3 \%)$ & $1(2,1 \%)$ \\
\hline POPLITEAL ARTERY ANEURYSM & $0(0 \%)$ & $1(2,1 \%)$ \\
\hline
\end{tabular}

Biomechanical analysis

Based on the values of RRED in 20 patients (41.67\%) decision to treat patient could be changed. Within these, 16 patients $(80 \%)$ would be transferred to the group of patients for further follow-up without surgi- cal treatment although their MD was higher than $55 \mathrm{~mm}$. Changing treatment decision is based on their RRED that was less than the limit of $55 \mathrm{~mm}$. The remaining 4 patients $(20 \%)$ could be subjected to surgical treatment because their RRED was higher than the limit of $55 \mathrm{~mm}$ (Scheme 1). 
THE BOUNDARY VALUE OF MAXIMUM AAA DIAMETER $55 \mathrm{~mm}$

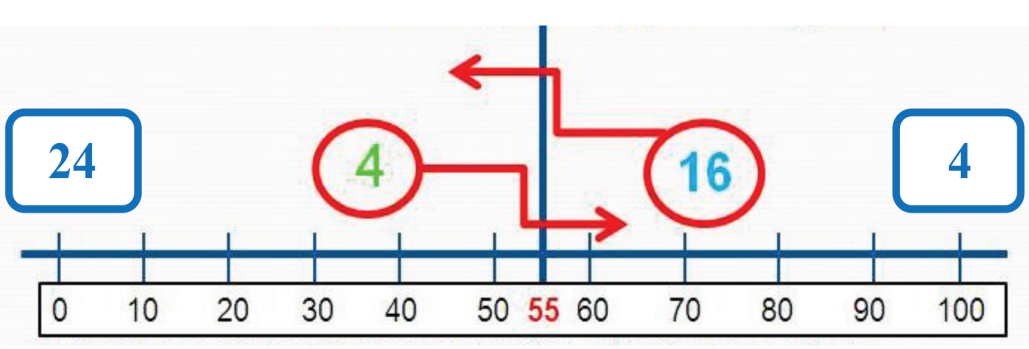

RUPTURE RISK EQUIVALENT DIAMETER (RRED in mm)

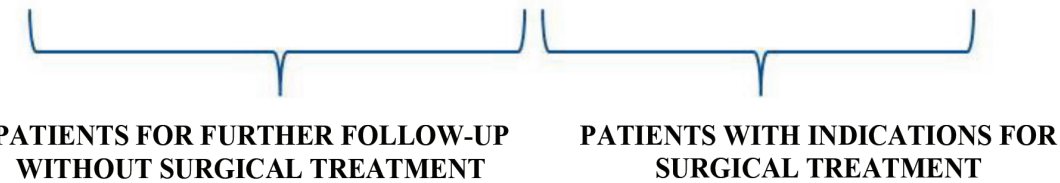

Scheme 1. In order to estimate the frequency of changes in the decision for surgical treatment, the patients were divided into 2 groups: 1 . At the left side of the boundary value of $55 \mathrm{~mm}$ is the first group of patients consisted of 28 patients, in whom RRED and MD were on the same side of the boundary values; 2 . At right side of the boundary value is the second group of patients consisted of 20 patients which RRED and MD values were from different sides of the boundary value. 4 patients (20\%) with aneurysm diameter (MD) less than $55 \mathrm{~mm}$ would be transferred to the group of patients with indications for surgical treatment because their RRED was higher than the limit of $55 \mathrm{~mm} .16$ patients $(80 \%)$ would be transferred to the group of patients for further follow-up without surgical treatment, because their RRED was less than the limit of $55 \mathrm{~mm}$ although their MD was higher than $55 \mathrm{~mm}$

Table 2. Values of parameters biomechanical analysis in the first and second group of patients (ST.DEV. standard deviation) values are in $\mathrm{mm}$.

\begin{tabular}{|c|c|c|c|c|c|}
\hline \multirow[b]{2}{*}{ PARAMETERS BIOMECHANICAL ANALYSIS } & \multicolumn{2}{|c|}{ FIRST GROUP } & \multicolumn{2}{|c|}{ SECOND GROUP } & \multirow[b]{2}{*}{ P VALUE } \\
\hline & $\begin{array}{l}\text { MEAN } \\
\text { VALUE }\end{array}$ & ST.DEV. & $\begin{array}{l}\text { MEAN } \\
\text { VALUE }\end{array}$ & ST.DEV. & \\
\hline MD & 57,98 & 18,88 & 60,72 & 8,73 & 0,549 \\
\hline RRED & 56,53 & 25,23 & 49,20 & 8,68 & 0,220 \\
\hline DIFFERENCE DIAMETER & $\begin{array}{c}9.97 \\
(16.69 \%)\end{array}$ & $\begin{array}{c}6.37 \\
(9.72 \%)\end{array}$ & $\begin{array}{c}16.44 \\
(26.73 \%)\end{array}$ & $\begin{array}{c}7.74 \\
(10.62 \%)\end{array}$ & $\begin{array}{r}0.003 * \\
(0.001)\end{array}$ \\
\hline MAXIMUM LUMINAL DIAMETER & 43,10 & 19.09 & 42.52 & 8.49 & 0.900 \\
\hline MAXIMUM THICKNESS OF THE INTRALUMINAL THROMBUS & 17.14 & 9.44 & 24.00 & 11,87 & $0.031^{\star}$ \\
\hline TOTAL VOLUME OF AAA (TVA) & 199.39 & 139.26 & 234.37 & 100.28 & 0.343 \\
\hline TOTAL LUMINAL VOLUME & 98.19 & 83.00 & 92.14 & 28.56 & 0.756 \\
\hline INTRALUMINAL THROMBUS VOLUME (ITV) & 76.82 & 70.90 & 112.59 & 81.49 & 0.112 \\
\hline TVA/ITV (\%) & $\begin{array}{c}4.08 \\
(36.79 \%)\end{array}$ & $\begin{array}{c}4.92 \\
(15.40 \%)\end{array}$ & $\begin{array}{c}3.79 \\
(43.38 \%)\end{array}$ & $\begin{array}{c}6.04 \\
(16.59 \%)\end{array}$ & $\begin{array}{c}0.856 \\
(0.164 \%)\end{array}$ \\
\hline MAXIMUM WALL STRESS (PEAK WALL STRESS) & 206.33 & 79.99 & 202.97 & 27.86 & 0.858 \\
\hline AVERAGE VALUE OF WALL STRESS & 103.74 & 25.14 & 104.89 & 16.42 & 0.859 \\
\hline $\begin{array}{l}\text { MAXIMUM VALUE OF THE INDEX THAT SHOWS RISK OF } \\
\text { RUPTURE (MIR) }\end{array}$ & 0.43 & 0.30 & 0.39 & 0.07 & 0.586 \\
\hline $\begin{array}{l}\text { AVERAGE VALUE OF THE INDEX THAT SHOWS RISK OF } \\
\text { RUPTURE (AIR) }\end{array}$ & 0.23 & 0.09 & 0.31 & 0.42 & 0.439 \\
\hline $\begin{array}{l}\text { MAXIMUM WALL STRESS IN THE AREA OF INTRALUMINAL } \\
\text { THROMBUS (MST) }\end{array}$ & 27.71 & 17.36 & 28.76 & 14.10 & 0.826 \\
\hline $\begin{array}{l}\text { AVERAGE VALUE OF THE WALL STRESS IN THE AREA OF } \\
\text { INTRALUMINAL THROMBUS (AST) }\end{array}$ & 6.97 & 1.18 & 53.43 & 206.55 & 0.238 \\
\hline $\begin{array}{l}\text { MAXIMUM VALUE OF THE INDEX THAT SHOWS THE RISK OF } \\
\text { RUPTURE IN THE REGION INTRALUMINAL THROMBUS (MIRT) }\end{array}$ & 0.46 & 0.37 & 0.47 & 0.22 & 0.900 \\
\hline $\begin{array}{l}\text { AVERAGE VALUE OF THE INDEX THAT SHOWS THE RISK OF } \\
\text { RUPTURE IN THE AREA OF INTRALUMINAL THROMBUS (AIRT) }\end{array}$ & 0.11 & 0.03 & 0.12 & 0.04 & 0.315 \\
\hline
\end{tabular}


The absolute difference of diameters value $(\mathrm{DD}=\mathrm{RRED}-\mathrm{MD})$ in the second group of patients was statistically significantly higher $(16.44 \pm 7.74 \mathrm{~mm}(26.73$ $\pm 10.62 \%)$ ) than difference of diameters in the first group $(9.97 \pm 6,37 \mathrm{~mm}(16.69 \pm 9.72 \%))(\mathrm{p}=0.003)$. The maximum thickness of intraluminal thrombus was significantly higher $(\mathrm{p}=0.03)$ in the second group $(24 \pm 11.87$ $\mathrm{mm}$ ) than the maximum thickness of the thrombus in the first group of patients $(17.14 \pm 9.44 \mathrm{~mm})$. The other corresponding biomechanical parameters, such as peak and average value of the wall stress and values of various indexes that indicate the risk of rupture, were compared between the two groups (Table 2).

\section{Discussion}

This study showed that taking into consideration biomechanical parameters would significantly change the decision how to treat patients with AAA.

When deciding to treat asymptomatic AAA we have to consider the risk of rupture and the risk of procedure. The risk of procedure is determined by location of the aneurysm and its extension, previous operations, surgical volumen the clinic and surgeon, general condition of the patient and other morbid conditions that might complicate recovery (cardiorespiratory and renal insufficiency). These factors are easier to define while on the other side risk of rupture is still controversial. Maximal diameter of AAA is a clinically valid and widely used predictor of rupture risk. Rupture risk increases exponentially with the diameter. For aneurysms with diameters smaller than $5 \mathrm{~cm}$, an expansion rate of $5 \mathrm{~mm}$ per year is a signal for elective surgery consideration, while the expansion rate of more than $10 \mathrm{~mm}$ per year is critical for the deciding on elective surgery [8]. After introduction of FEM and possibility to analyse wall stress distribution in the aneurysm sac as well as values and location of its highest value, peak wall stress, numerous studies showed that this method is more accurate in rupture prediction than maximal diameter. It was proved also in the recently published meta [9]. Even after these studies biomechanical analysis is not in the regular clinical practice, this was the reason that we aimed this study to assess potential changes in our future clinical practice if biomechanical parameteres were used.

In accordance with the value of RRED, we found that in the patients with a significant percentage $(41.67 \%)$ could receive an altered treatment decision. In that way, the majority of patients which had a maximum AAA diameter greater than $55 \mathrm{~mm}$, would be spared from operational risk, because the analysis of relevant biomechanical parameters (primarily RRED) proved that their aneurysms have smaller risk of rupture than expressed by maximal diameter. Even those patients might avoid surgical repair if done by minimal invasive procedure (endovascular) or by experienced team and surgeon, risk of such procedure would be less than $1 \%$. On the other side changing decision in the direction of surgery would have been in $20 \%$ of the total number of those whose maximum AAA diameter was less than $55 \mathrm{~mm}$. Namely, these patients would usually be left untreated with the higher risk of rupture that might occur during survailance. Leaving patient untreated with potentially deadfull condition might be more dangerous decision than to treat patients with low risk procedure.

These, our results are in correlation with Filinger's et al. results (2003), where in a group of patients with symptomatic or ruptured AAA,there were $23 \%$ of patients whose AAA diameter measured was less than 50 $\mathrm{mm}$ [10]. In support of the fact, that our results confirm the discrepancy between the measured diameter and maximum stress in the wall of AAA, are the results of other studies that have shown that the incidence of ruptured AAA smaller than $55 \mathrm{~mm}$ ranges from $10 \%$ to $24 \%$ $[11,12]$.

From the foregoing it appears that the maximum AAA diameter measured parameter is not ideal when it comes to assessing the risk of rupture and RRED established itself as a comprehensive parameter that takes into account other determinants such as maximum and the average value of stress in the wall AAA, various indices point to the risk of rupture and the thickness of intraluminal thrombus. Also, it is important to take into account the strength of the wall AAA and its distribution, because it has been shown that the strength of the wall is different in different parts of the aneurysm and is generally less where the wall is thinner or where is the presence of intraluminal thrombus [13].

Therefore, in addition to stress values in the AAA, wall strength must be taken into account, because the two aneurysms with the same value of stresses and different values wall strength have different potential for rupture [14]. Also, the impact of an intraluminal thrombus as a marker of increased risk for ruptured AAA in various studies is controversial. Results of some studies suggest that its presence increases the risk of rupture, while other studies show a smaller or no effect at all $[12,15,16,17]$. Labudovic Borovic et al. confirmed in their study that the presence of a thrombus specially affects small aneurysms. Small aneurysms with thrombus had the thinnest wall, but very thick media and thick adventitia at the same time. In the contact area between the thrombus and aneurysm wall, the level of MMP2/MMP9 is significantly increased. There are a lot of neutrophilic granulocytes that are the primary source of MMP2 and MMP9 in this area [18]. The significant destruction of 
the medial layer and reinforcement of the adventitia in small aneurysms is a consequence of intensive inflammation in aneurysms, combined with destructive influence of the thrombus to the structure of the medial layer and a reparative increase of the adventitia. These features significantly increase the risk of rupture in small aneurysms with the thrombus [19]. Wall thickness increases with the dilatation of aneurysms and the presence of a thrombus. There are research groups that considered these features as protective. Namely, these groups considered that the thrombus, together with a thick wall, had a cushion effect which reduced the mechanical stress in the wall [20]. Our results showed that the thickness of the intraluminal thrombus was significantly higher in the second group, which can be explained by the fact that the values of the maximum AAA diameters measured in this group were higher and there was more space that enabled the creation of a large thrombus. The thickness of the thrombus is, inter alia, the consequence of different geometry AAA, it is necessary to examine a larger number of patients in order to draw valid conclusions about whether thrombi really contribute to a higher risk of aneurysm rupture. Risk factors that reduce the strength of the wall of the abdominal aorta and the mechanisms that operate are not entirely clear [21]. There was a connection between certain variables with an increased risk of AAA rupture and we have considered some of them in the framework of the existing characteristics and comorbidity in patients. Namely, in elderly, balance between synthesis and degradation of collagen and elastic fibers is moved to the side of increased degradation. This is contributed to increased gene expression of matrix metalloproteinases as well as increased secretion of cytokines by the inflammatory cells, all of which compromise the aortic wall strength [22]. In addition, epidemiological studies have shown a higher prevalence of AAA in older people [23]. Patients in both our groups were mostly older than 65 years.

One of the limitations of our study is small sample size. Since this paper is part of the project that includes larger number of patients, this limitation could be improved in studies that will follow. This study has observational nature and assesses conditional, potential influence of this new method on our clinical decision making and requires further clinical validation. Patients included in the study were not followed clinically.

By FEM and subsequent biomechanical analysis in patients with AAA we found that in almost half of patients who were part of the study could change decision about treatment of AAA. Despite the fact that these results are still preliminary and described the method has not yet been introduced to a general clinical practice, its positive effect in the precise decision on how to treat patients with AAA is already looming.

\section{References}

1. Gillum RF. Epidemiology of aortic aneurysm in the United States. J Clin Epidemiol. 1995; 48(11):1289-1298.

2. Chaikof EL, Brewster DC, Dalman RL, Makaroun MS, Illig KA, Sicard GA et al. The care of patients with an abdominal aortic aneurysm: the Society for Vascular Surgery practice guidelines. J Vasc Surg. 2009; 50(4):S2-49.

3. Nicholls SC, Gardner JB, Meissner MH, Johansen HK. Rupture in small abdominal aortic aneurysms. J Vasc Surg. 1998; 28(5):884-888.

4. Darling RC, Messina CR, Brewster DC, Ottinger LW. Autopsy study of unoperated abdominal aortic aneurysms. The case for early resection. Circulation. 1977; 56(3):II161-164.

5. Raghavan ML, Vorp DA, Federle MP, Makaroun MS, Webster MW. Wall stress distribution on three-dimensionally reconstructed models of human abdominal aortic aneurysm. J Vasc Surg. 2000; 31(4):760-769.

6. Brown PM, Zelt DT, Sobolev B. The risk of rupture in untreated aneurysms: the impact of size, gender, and expansion rate. J Vasc Surg. 2003; 37(2):280-284.

7. Kontopodis N, Metaxa E, Papaharilaou Y, Georgakarakos E, Tsetis D, Ioannou CV. Value of volume measurements in evaluating abdominal aortic aneurysms growth rate and need for surgical treatment. Eur J Radiol. 2014; 83(7):1051-1056.

8. Leung JH, Wright AR, Cheshire N, Crane J, Thom SA, Hughes $\mathrm{AD}$ et al. Fluid structure interaction of patient specific abdominal aortic aneurysm: a comparison with solid stress models. Biomed Eng OnLine, 2006; 5: 33.

9. Erhart P, Hyhlik-Dürr A, Geisbüsch P, Kotelis D, Müller-Eschner M, Gasser TC et al. Finite element analysis in asymptomatic, symptomatic, and ruptured abdominal aortic aneurysms: in search of new rupture risk predictors. Eur J Vasc Endovasc Surg. 2015 Mar;49(3):239-245.

10. Brown LC, Powell JT. Risk factors for aneurysm rupture in patients kept under ultrasound surveillance. UK Small Aneurysm Trial participants. Ann Surg. 1999; 230:289296.

11. Nicholls SC, Gardner JB, Meissner MH, Johansen HK. Rupture in small abdominal aortic aneurysms. J Vasc Surg. 1998; 28:884-888.

12. Lee PC, Wang DH, Makaroun MS, Vorp DA, Nemoto EM, Ogawa $S$ et al. Association of intraluminal thrombus in abdominal aortic aneurysm with local hypoxia and wall weakening. J. Vasc. Surg. 2001: 34(2):291-299.

13. Raghavan ML, Vorp DA, Federle MP, Makaroun MS, Webster MW. Wall stress distribution on three-dimensionally reconstructed models of human abdominal aortic aneurysm. J. Vasc. Surg. 2000: 31(4):760-769.

14. Schurink GW, van Baalen JM, Visser MJ, van Bockel JH. Thrombus within an aortic aneurysm does not reduce pressure on the aneurismal wall. J Vasc Surg 2000;31:501506.

15. Wassef M, Baxter TB, Chisholm RL, Dalman RL, Fillinger MF, Heinecke J et al. Pathogenesis of abdominal aortic aneurysms: a multidisciplinary research program supported 
by the National Heart, Lung and Blood Institute. J Vasc Surg. 2001; 34:730-738.

16. Mower WR, Quinones WJ, Gambhir SS. Effect of intraluminal thrombus on abdominal aortic aneurysm wall stress. J Vasc Surg 1997; 26:602-608.

17. Di Martino E, Mantero S, Inzoli F, Melissano G, Astore D, Chiesa $\mathrm{R}$ et al. Biomechanics of abdominal aortic aneurysm in the presence of endoluminal thrombus: experimental characterisation and structural static computational analysis. Eur J Vasc. Endovasc Surg 1998; 15:290-299.

18. Fontain V, Touat Z, Mtairag el M, Vranckx R, Louedec L, Houard X et al. Role of leukocyte elastase in preventing cellular re-colonization of the mural thrombus. Am. J. Pathol., 2004; 164: 2077- 87.

19. Labudović Borović M, Borović S, Radak Đ, Marinković-Erić J, Maravić-Stojković V, Vučević D. et al. Morphometric model of abdominal aortic aneurysms and the significance of the structural changes in the aortic wall for rupture risk assessment, in: aortic aneurysms: risk factors, diagnosis, surgery and repair. Fischhof D and Hatig F, editors. New York, Hauppauge: Nova Science Publishers, Inc., 2013; 81-117.

20. Di Martino ES, Vorp DA. Effct of variation in intraluminal thrombus constitutive properties on abdominal aortic aneurysm wall stress. Ann. Biomed. Eng., 2003; 31: 804-9.

21. Jacob MP, Fontaine CV, Benazzoug YC, Feldman L, Michel JB. Extracellular matrix remodeling in the vascular wall. Pathol. Biol. 2001; 49(4):326-332.

22. Blanchard JF. Epidemiology of Abdominal Aortic Aneurysms. Epidemiol. Rev. 1999; 21(2):207-221.

23. Bengtsson $\mathrm{H}$, Sonesson B, Bergqvis D. Incidence and prevalence of abdominal aortic aneurysms. estimated by necropsy studies and population screening by ultrasound. Ann. N.Y. Acad Sci. 1996; 800:1-24. 